\title{
Motivation and Work Discipline on Employee Performance: A Case Study at One of the Mechanical and Electronic Importer Companies in Indonesia
}

\author{
Agus Arijanto \\ Lecturer of Economic and Business Faculty, Universitas Mercu Buana Jakarta and also as a Post-Graduate \\ Student, Doctor of Management Science at Jenderal Sudirman University at Purwokerto
}

\begin{abstract}
This study aims to determine the effect of Motivation on Employee Performance at PT Fajar Benua Indopack, to determine the effect of Work Discipline on Employee Performance at PT Fajar Benua Indopack, and to determine how much influence the Work Motivation and Discipline on Employee Performance at PT Fajar Benua Indopack. Engineering, a mechanical and electrical importer company, with sampling in this study is using a systematic probability sampling method using a sample of 92 people. This research concludes that Motivation and Work Discipline have sufficient influence on Employee Performance.
\end{abstract}

Keywords : Motivation, Work Discipline, Employee Performance

DOI: $10.7176 / \mathrm{JCSD} / 45-06$

\section{Background}

The current era of globalization has an impact on business development. The most obvious impact is the existence of competition in the business world. The competition is getting tougher, making the company keep on competing to innovate to win the competition. The company will strive to achieve goals effectively and efficiently. This is done so that the company is able to have competitiveness and excellence from its competitors. The advantages of a company can be achieved through several factors. One of these factors is the company's internal capabilities or through the resources owned by the company.

In 2015 the era of globalization began to converge and focus on becoming the Asean Economic Community (MEA) which made competition not only in the business world but also in the competition of resources owned. In recruiting HR, the company makes specific criteria needed by the company. The recruitment process between one company and another varies depending on the analysis of HR requirements needed. In a company operational system, the potential of human resources is essentially one of the capital and holds the most important role in achieving company goals. Human resources are an important aspect to support the productivity of a company in order to be able to survive in the current tight business competition.

Employees play a major role in running the wheels of corporate life. If employees have high productivity and work motivation, then the speed of the wheels will run fast and eventually will produce good performance and achievement for the company. But on the contrary, if employees work unproductively and do not have high morale, they are not resilient in working and have low morale, which can reduce company performance.

Motivation is a process that generates, directs and maintains or maintains human behavior so that it is aimed at purpose. To further improve performance and positive attitudes, you should use and focus on motivating factors. Work motivation has a positive and significant effect on company performance, meaning that work motivation is very influential on job satisfaction and affects company performance. Motivation is the reason, the impulse that is in human beings that causes people to do something or do something. 
To create the performance of employees who have a high work ethic, it is not only driven by motivation but also with high work discipline. Discipline was created to make everything go according to procedure. With discipline, all the work done can be done to the maximum and with satisfactory results. Work discipline is a form of obedience from a person's behavior in complying with certain provisions or regulations relating to work and applied in an organization. Work discipline needs to be owned by everyone so that the life of the organization can be safe and smooth.

There are so many problems surrounding human resource management that cause companies to experience setbacks. This problem will eventually develop into a complex problem that results in all aspects of the company. The problem that arises is caused by the work discipline of employees in work. One indication of the decline in the level of work discipline is the presence of employees who do not comply with company regulations, such as data and absenteeism of employees who rarely enter work, so the employee receives a warning letter from the company. Based on data obtained from PT Fajar Benua Indopack, there are 120 employees and there are some who often do not come to the office. The data can be seen from

Table 1.1 Employee Attendance Data of PT Fajar Benua Indopack Period : February 2017 to April 2017

\begin{tabular}{|l|c|c|c|c|c|c|c|c|}
\hline \multirow{3}{*}{ Month } & \multicolumn{9}{|c|}{ Description } \\
\cline { 2 - 9 } & \multicolumn{2}{|c|}{ Sick } & \multicolumn{2}{c|}{ Permission } & \multicolumn{2}{c|}{ Alfa } & \multicolumn{2}{c|}{ Leave } \\
\cline { 2 - 9 } & Total & $\%$ & Total & $\%$ & Total & $\%$ & Total & $\%$ \\
\hline February & 20 & $13 \%$ & 5 & $3 \%$ & 15 & $10 \%$ & 19 & $13 \%$ \\
\hline March & 21 & $14 \%$ & 4 & $3 \%$ & 11 & $7 \%$ & 27 & $18 \%$ \\
\hline April & 10 & $7 \%$ & 12 & $8 \%$ & 14 & $9 \%$ & 24 & $16 \%$ \\
\hline
\end{tabular}

Source : Human Resources Dept . (2017)

Table 1.1 shows the attendance level of PT Fajar Benua Indopack employees for the period February 2017 to April 2017. The average percentage of absence per month is $10 \%$. This absence has an impact on employee performance so that the target of PT Fajar Benua Indopack in that period was not realized in accordance with the plan set at the beginning. The data can be seen from the table below :

Table 1.2 : Data on Delays in Employees of PT Fajar Benua Indopack Period of February 2017 to April 2017

\begin{tabular}{|l|c|c|c|}
\hline Month & Total Delay & $\begin{array}{c}\text { Total Employee } \\
\text { Entrance }\end{array}$ & Delay Percentage \\
\hline February & 487 & 2868 & $17 \%$ \\
\hline Maret & 563 & 3329 & $17 \%$ \\
\hline April & 534 & 3014 & $18 \%$ \\
\hline
\end{tabular}

Source : Human Resources Dept. (2017)

According to table 1.2 regarding data on the delay of PT Fajar Benua Indopack employees for the period February 2017 to April 2017 shows that the total delay each month has increased. The lack of discipline that 
employees have to attend on time has an impact on employee performance and has a negative effect on the company.

From the two tables above, it can be said that the level of attendance and delay of PT Fajar Benua Indopack employees is unsatisfactory and has an impact on employee performance. This illustrates the lack of motivation of employees to be more disciplined due to the absence of strict sanctions for employees who are unable to attend or late. Lack of strict regulations regarding the presence or delay caused employees to lack motivation to attend and work according to the prevailing rules and regulations of the company.

\section{LITERATURE REVIEW}

\section{Employee performance}

Expected work performance is a standard achievement prepared as a reference so that it can see employee performance in accordance with its position compared to the standards made. In addition, it can also be seen the performance of these employees towards other employees. Internal factors and external factors above are types of attribution that affect a person's performance. According to Daft (2000) in Shahzad (2013: 57), employee performance means the ability of employees to achieve goals both personal or organizational by using resources efficiently and effectively. According to Rivai (2014: 604) performance is a term in general that is used in part or all actions or activities of an organization in a period with a reference to a number of standards such as past costs projected on the basis of efficiency, accountability or management accountability and the like.

Whereas according to Sihombing, The Effect of Organizational Culture and Leadership Style on Employee Performance, Business Management Scientific Journal, Mercu Buana University, Volume 4, No. 02, July 2016, Performance (work performance) is the work of quality and quantity achieved by an employee in carrying out his duties in accordance with the responsibilities given to him when compared to a set of performance standards. This assessment is also referred to as employee assessment, worker evaluation, performance review, work performance assessment and outcome assessment. Performance can be interpreted as the level of success in carrying out tasks as well as the ability to achieve set goals. By having high performance, employees will work based on work plans, pay attention to work processes and result oriented. According to David (2002) in Sundi (2013: 53) one of the key factors that influence employee performance is work motivation.

According to Mangkunegara (2012: 9) employee performance is the result of work in quality and quantity achieved by an employee in carrying out his duties in accordance with the responsibilities given to him. So that from some expert opinions it can be concluded that employee performance is the work of quality and quantity carried out by someone in an organization in order to achieve the objectives desired by an organization and minimize losses and be able to create reliable employees who are able to carry out their duties according to the responsibilities given.

\section{Motivation}

Motivation According to Sutrisno (2013: 109) that the factors that encourage a person to do a certain activity, motivation is often interpreted as a driving factor for one's behavior. And motivation according to Mangkunegara (2012: 93) that the conditions or energy that moves employees are directed or aimed at achieving 
the goals of the company's organization. Motivation According to Wibowo (2012: 379) that motivation is an encouragement to a series of processes of human behavior on achieving goals.

Furthermore, the theory of Motivation of Needs (Maslow's hierarchy of needs model) was stated by Maslow. In this theory, humans are motivated to behave or carry out activities because of various necessities of life (Daft, 2010: 444). Maslow views that humans are motivated because of five needs arranged as a hierarchy. The hierarchical conception of needs expressed by A. Maslow is (1) The need for self-actualization (self actualization needs), namely the use of self-potential, growth, self-development such as completing challenging assignments, doing creative work and developing skills. (2) Self-esteem needs (esteem needs), namely status or position, self-confidence, recognition, reputation and achievement, appreciation, self-respect, awards such as power, ego, promotion, gifts, status, symbol, position recognition, awards. (3) Social needs (social needs), namely love, affection, friendship, feeling of belonging and being accepted in groups, family and socialization such as formal and informal working groups, company-sponsored activities or commemorative events. 4) Security and security needs, namely protection and stability such as employee development, safe working conditions, plans for union seniority, savings, severance pay, pension guarantees, insurance, complaints handling systems. 5) Physiological needs (phisiological needs), namely eating, drinking, housing, sex, rest, rest room, clean air for breathing, water for drinking, vacation, leave, remuneration and social security, periods of rest on the job. And according to Anik Herminingsih, (2016), The Effect of Training, Work Motivation and Organizational Culture on Civil Servant Performance, Economic and Social Journal, Universitas Mercu Buana, Vol. 5, 2016 states that states that achievement, power / relationships and relationships are three important needs that can help explain motivation. Achievement needs are a drive to exceed, achieve standards, and strive to succeed. Strength needs can make others behave in such a way that they will not behave otherwise and relationship needs are friendly and intimate interpersonal desires within the organization.

Based on the definition of the experts above, it can be concluded that, motivation is an encouragement of the needs of the employees that need to be fulfilled so that employees can adjust to their environment. Therefore, motivation is a reason for someone to act in order to fulfill their needs

\section{Work Discipline}

According to Hasibuan (2012: 193) work discipline is a person's awareness and willingness to comply with all applicable company regulations and social norms. And According to Latainer in Sutrisno (2013: 87) which defines discipline as a power that develops within the body of the employee and causes employees to be able to adjust voluntarily to decisions, regulations, and high values of work and behavior. In a narrow sense, it is usually associated with punishment. Even though actually punishing an employee is only a matter of discipline.

Whereas according to Rivai (2014: 825) work discipline is a tool used by managers to communicate with employees so that they are willing to change a behavior and as an effort to increase awareness and willingness of a person to fulfill all company regulations. From several definitions of work discipline proposed by several experts it can be concluded that work discipline is an attitude of awareness, willingness and willingness of someone to comply with and obey the rules and social norms that apply in the surrounding environment. 


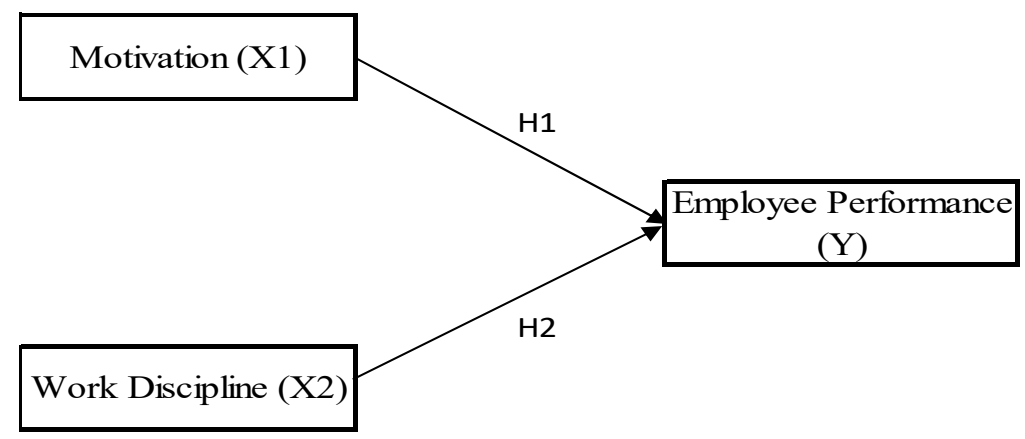

Figure 2.1 CONCEPTUAL FRAMEWORK

\section{RESEARCH HYPOTHESES}

$\mathrm{H}_{1}$ : Motivation (X1) has a positive impact on Employee Performance (Y) at

PT Fajar Benua Indopack

$\mathrm{H}_{2}$ : Work Discipline (X2) has a positive impact on Employee Performance

(Y) at PT Fajar Benua Indopack

\section{RESEARCH METHODS}

The type of research used in this study is quantitative. Based on these theories, quantitative research in this study is to measure the variables that are there and then find the relationship between Work Motivation and Discipline on Employee Performance at PT Fajar Benua Indopack which is then analyzed according to the statistical method used. The method used in this study is a quantitative causal method using the SPSS 23 statistical analysis program.

\section{RESEARCH POPULATION AND SAMPLE}

Population is the subject of research. According to Sugiyono (2014: 119) the population is a region of generalization, object or subject that has certain qualities and characteristics set by the researcher to be studied and then conclusions drawn. The population in this study used 120 employees at PT Fajar Benua Indopack. And the total population will be sampling in this study.

\section{DATA COLLECTION TECHNIQUE}

The data used in this study are Primary Data. According to Sugiyono (2014: 193) Primary Data is a data source that directly provides data to data collectors. Data collected in this study used survey techniques by distributing questionnaires as a tool. According to Sugiyono (2014: 142) questionnaire is a technique of data collection conducted by giving a set of questions and written statements to the respondent to answer them. Questionnaires are efficient data collection techniques if researchers know for sure which variables to measure and know what can be expected from respondents. Respondents at this researcher were employees of PT Fajar Benua Indopack. 


\section{RESULTS AND DISCUSSION}

\section{Normality Test Results}

The normality test aims to test whether in the regression model, the use or residual variable has a normal distribution or not. A good regression model can be known by using a histogram graph, which can be seen if the data has a normal or near normal distribution.

\section{Multicollinearity Test Results}

Multicollinearity test aims to test whether the regression model found a correlation between one or all independent variables. Multicollinearity is used to test a model whether there is a perfect or almost perfect relationship between independent variables, so it is difficult to separate the influence between these variables individually on the dependent variable. This test is to find out whether the independent variables in the regression equation are not correlated with each other. To detect multicollinearity is to look at the value of tolerance and the value of Variance Inflation Factor (VIF), where the variable is said to have a multicollinearity problem if the tolerance value is less than 0.1 or the VIF value is greater than 10 .

Table 4.12 Multicollinearity Test Results

\section{Coefficients $^{\mathrm{a}}$}

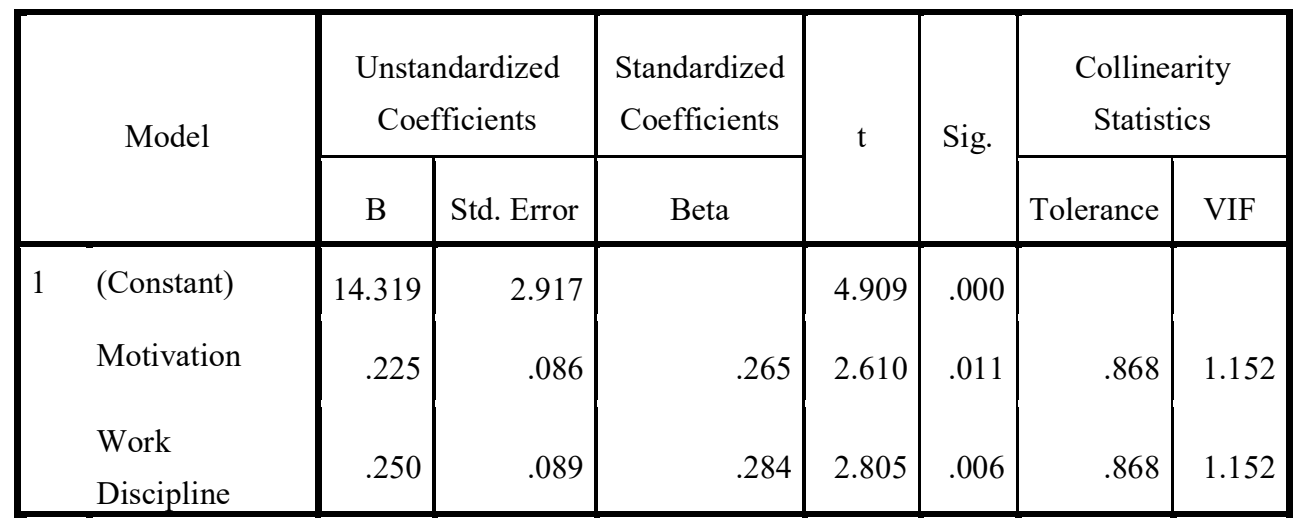

a. Dependent Variable: Employee Performance Sumber : Data Proceeed 2018

\section{Correlation Analysis Test Results}

Table 4.13 Correlation Analysis Test Results

Model Summary

\begin{tabular}{|c|c|c|c|c|c|c|c|c|c|}
\hline \multirow[b]{2}{*}{ Model } & \multirow[b]{2}{*}{$\mathrm{R}$} & \multirow{2}{*}{$\begin{array}{c}\mathrm{R} \\
\text { Square }\end{array}$} & \multirow{2}{*}{$\begin{array}{l}\text { Adjusted } \\
\text { R Square }\end{array}$} & \multirow{2}{*}{$\begin{array}{l}\text { Std. Error } \\
\text { of the } \\
\text { Estimate }\end{array}$} & \multicolumn{5}{|c|}{ Change Statistics } \\
\hline & & & & & $\begin{array}{c}\text { R Square } \\
\text { Change }\end{array}$ & $\begin{array}{c}\mathrm{F} \\
\text { Change }\end{array}$ & df1 & df2 & $\begin{array}{l}\text { Sig. F } \\
\text { Change }\end{array}$ \\
\hline 1 & $.453^{\mathrm{a}}$ & .206 & .188 & 2.48409 & .206 & 11.511 & 2 & 89 & .000 \\
\hline
\end{tabular}

a. Predictors: (Constant), Work Discipline, Motivation

b. Dependent Variable: Employee Performanace Source : Data processed 
Based on table 4.13 the results of Sig. F Change 0,000 then discipline and motivation variables simultaneously related to employee performance variables. While the R value (correlation coefficients) is 0.453 which means the degree of relationship between work discipline variables and motivation on the performance of employees into the category of moderate correlation.

\section{Test of Multiple Regression Analysis}

Table 4.14 : Test Results for Multiple Regression Analysis

\begin{tabular}{|c|c|c|c|c|c|c|}
\hline & \multirow[b]{2}{*}{ Model } & \multicolumn{2}{|c|}{$\begin{array}{l}\text { Unstandardized } \\
\text { Coefficients }\end{array}$} & \multirow{2}{*}{$\begin{array}{c}\begin{array}{c}\text { Standardized } \\
\text { Coefficients }\end{array} \\
\text { Beta }\end{array}$} & \multirow[b]{2}{*}{$\mathrm{t}$} & \multirow[b]{2}{*}{ Sig. } \\
\hline & & B & Std. Error & & & \\
\hline \multirow[t]{3}{*}{1} & (Constant) & 14.319 & 2.917 & & 4.909 & .000 \\
\hline & Motivation & .225 & .086 & .265 & 2.610 & .011 \\
\hline & $\begin{array}{l}\text { Work } \\
\text { Discipline }\end{array}$ & .250 & .089 & .284 & 2.805 & .006 \\
\hline
\end{tabular}

a. Dependent Variable: Employee Performance

$$
\mathrm{Y}=14.319+0.225 \mathrm{X}_{1}+0.250 \mathrm{X}_{2}
$$

1. Motivation and Work Discipline have a significant impact on Employee Performance.

2. The motivation variable regression coefficient of 0.225 and a positive value on employee performance.

3. The regression value coefficient of the work discipline's variable is equal to 0.250 and a positive value for employee performance.

\section{Model Suitability Test Results}

Table 4.15 Determination Coefficient Test Results

Model Summary
\begin{tabular}{|l|r|r|r|r|}
\hline Model & \multicolumn{1}{c|}{ R } & R Square & Adjusted R Square & Std. Error of the Estimate \\
\hline 1 & $.453^{\mathrm{a}}$ & .206 & .188 & 2.48409 \\
\hline
\end{tabular}

a. Predictors: (Constant), Work Dicipline, Motivation

Sumber : Data Diolah Penulis 2018

From the results of computerized data processing using the SPSS program the determination coefficient $(\mathrm{R} 2)=$ 0.206 is obtained. This indicates that $20.6 \%$ of employee performance variables are explained by motivation and work discipline variables, while the rest $(100 \%-20.6 \%=79.4 \%)$ are explained or influenced by other factors not examined.

\section{Simultaneous Test (Test of F Statistics)}

Hypothesis testing simultaneously (whole) by using " $F$ test" that is by looking for " $F$ count" and comparing with "F table". 


\begin{tabular}{|r|r|c|c|}
\hline \multicolumn{1}{|c|}{ df } & Mean Square & F & Sig. \\
\hline 2 & 71.028 & 11.511 & $.000^{\mathrm{b}}$ \\
89 & 6.171 & & \\
91 & & & \\
\hline
\end{tabular}

a. Dependent Variable: Kinerja Karyawan

b. Predictors: (Constant), Disiplin Kerja, Motivasi

Simultaneously testing $X 1$ and $X 2$ against $Y$ :

From table 4.16 , the calculated $\mathrm{F}$ value is 11,511 with a probability value $(\mathrm{sig})=0,000$. The calculated $\mathrm{F}$ value is greater than $\mathrm{F}$ table $11.511>3.10$, and the sig value is smaller than the probability value of 0.05 or the value of $0.000<0.05$; the meaning is together (simultaneously) Motivation and Work Discipline have a significant effect on Employee Performance.

\section{Hypothesis Test Results}

1. Individual Parameter Significance Test (Test Statistic t)

The $\mathrm{t}$ test is used to show how far the influence of one independent variable individually in explaining the dependent variable by comparing the $t$ table with $\mathrm{t}$ count.

Table 4.17 : Test Results $t$

\section{Coefficients ${ }^{\mathrm{a}}$}

\begin{tabular}{|c|c|c|c|c|c|c|}
\hline & \multirow[b]{2}{*}{ Model } & \multicolumn{2}{|c|}{$\begin{array}{c}\text { Unstandardized } \\
\text { Coefficients }\end{array}$} & \multirow{2}{*}{$\begin{array}{c}\begin{array}{c}\text { Standardized } \\
\text { Coefficients }\end{array} \\
\text { Beta }\end{array}$} & \multirow[b]{2}{*}{$\mathrm{t}$} & \multirow[b]{2}{*}{ Sig. } \\
\hline & & $\mathrm{B}$ & Std. Error & & & \\
\hline \multirow[t]{3}{*}{1} & (Constant) & 14.319 & 2.917 & & 4.909 & .000 \\
\hline & Motivation & .225 & .086 & .265 & 2.610 & .011 \\
\hline & $\begin{array}{l}\text { Work } \\
\text { Dicipline }\end{array}$ & .250 & .089 & .284 & 2.805 & .006 \\
\hline
\end{tabular}

a. Dependent Variable: Employee Performance

Source : Data processed

Test results obtained ;

1. $\mathrm{X}_{1}$ (Motivation) the value of $\mathrm{t}$ count $2.610>\mathrm{t}$ table 1.990 thus the Motivation variable (X1) has a significant effect on Employee Performance (Y)

2. $\mathrm{X}_{2}$ (Work Discipline) the value of $\mathrm{t}$ count $2.805>\mathrm{t}$ table 1.990 so that the Work Discipline variable (X1) has a significant effect on Employee Performance (Y) 


\section{Discussion of Research Results}

According to the results of calculations and analysis above, the multiple linear regression equation is obtained as follows :

$$
Y=14,319+0.225 X_{1}+0.250 X_{2}
$$

The results of multiple linear regression equations show that the Motivation variable $(\mathrm{X} 1)=0.225$ and Work Discipline $(\mathrm{X} 2)=0.250$ are positive for Employee Performance. This means that if Work Motivation and Discipline is increased, Employee Performance at PT. Dawn of Continent Indopack. Motivation and Work Discipline variables together have a significant effect on Employee Performance. This is supported by the results of $F$ count of 11,511 with a significance value of 0,000 smaller than 0.05 . This means that if Work Motivation and Discipline are carried out jointly it will affect Employee Performance at PT. Dawn of Continent Indopack. Explanation of each variable influence can be explained as follows :

Relationship Motivation (X1) to Employee Performance (Y) based on the results of hypothesis testing (H1) has proven that there is an influence between Motivation on Employee Performance, through the results of calculations that have been obtained obtained $\mathrm{t}$ value equal to 2.610 greater than $\mathrm{t}$ table (1.990), with the significance value of 0.011 is smaller than 0.05 . The results above state that the first hypothesis is that it is suspected that motivation has an influence on employee performance at PT. Dawn of Continent Indopack, accepted.

The Relationship of Work Discipline (X2) to Employee Performance (Y) based on the results of hypothesis testing $(\mathrm{H} 2)$ has proven that there is an influence between Work Discipline on Employee Performance. Through the results of the calculations that have been made obtained value of t count of 2.805 is greater than t table (1.990) with a significance value of 0.006 smaller than 0.05 . The above results state that the second hypothesis, which is assumed to be Work Discipline, has an influence on Employee Performance at PT. Dawn of Continent Indopack, accepted.

According to the test results above it can be concluded that the two variables have a significant influence on Employee Performance. The relationship between independent variables Motivation (X1) and Work Discipline (X2) on the dependent variable (Y), proves that there is an influence between Motivation and Work Discipline on Employee Performance, through the results of calculations that have been obtained obtained F count of 11.511 greater than F table (3.10) with a significance of 0,000 smaller than 0.05 . This shows that simultaneously there is an impact to Work Motivation and Discipline on Employee Performance at PT Fajar Benua Indopack received.

\section{CONCLUSIONS AND SUGGESTIONS}

This conclusions can convey after conducting research and discussion on the effect of Motivation and Work Discipline on Employee Performance as follows :

1. Motivation has a positive and significant influence on the performance of PT Fajar Benua Indopack Employees. So, if work motivation is carried out and applied properly by all employees, the employee's performance will also increase. This can be interpreted the higher the motivation the higher the Employee Performance. 
2. Work Discipline has a positive and significant influence on the Performance of Employees of PT Fajar Benua Indopack. So, if employees have high discipline in their work, the employee's performance will also be achieved and experienced an increase. This can be interpreted the higher the Work Discipline the higher the Employee Performance.

\section{Suggestion}

According to the conclusions at above, the author suggestions are as follows :

1. Companies must always maintain the Work Motivation and Discipline in the company, because this factor is a factor that influences employee involvement and performance. Can be seen from the lowest coefficient of each variable item.

a) Referring to the motivation variable, it can be seen from the lowest coefficient on the statement about social needs, it is better for the company to impose an employee transition period or an introduction to new employees so that new employees can socialize easily.

b) Referring to the work discipline variables, it can be seen from the lowest coefficients on statements about initiative and creativity, it is better for PT Fajar Benua Indopack leaders to increase motivation from leaders to employees by providing opportunities for creativity and initiative in working and providing opportunities to develop skills and ability to work.

c) Referring to employee performance variables, it can be seen from the lowest coefficient on the statement about the quantity of work, the company should measure the workload of employees so that employees can complete the workload according to the ability of the employee itself.

2. For the next researcher, it is necessary to add other variables and not only limited to Motivation, Work Discipline, Employee Performance variables, because there are other possibilities for more significant variables.

\section{BIBLIOGRAPHY}

A.A.Awar Prabu Mangkunegara. (2012). Company Human Resource Management. PT.Remaja Rosda Karya, Bandung.

Abdullah, Ma'aruf. (2014). Management and Evaluation of Employee Performance: Aswanda Pressindo, Yogyakarta.

Anik Herminingsih, (2016), The Effect of Training, Work Motivation and Organizational Culture on Civil Servant Performance, Economic and Social Journal, Universitas Mercu Buana, Vol. 5, 2016

Edy, Sutrisno. (2013). Human Resource Management, First Edition, Kencana, Jakarta.

Hasibuan, Malayu S.P. (2012). Human Resource Management, PT Bumi Aksara, Jakarta.

Moeheriono. (2012). Competency-Based Performance Measurement, RajaGrafindo Persada, Jakarta.

Sandy Martha, Muhammad. (2015). "Job Characteristics and Performance of Extraordinary Lecturers UIN Sunan Gunung Djati Bandung: Organizational Commitment as Moderating Variables". Thesis at Widayatama University, Bandung. 
Sihombing, The Effect of Organizational Culture and Leadership Style on Employee Performance, Business Management Scientific Journal, Mercu Buana University, Volume 4, No. 02, July 2016

Sinambela, Lijan Poltak. (2012). Employee Performance Measurement Theory and Implications, Graha Ilmu, Yogyakarta.

Sondang P. Siagian. (2012). Human Resource Management, PT. Bumi Aksara, Jakarta.

Sunyoto, D. (2012). Human Resource Management, CAPS, Yogyakarta.

Sugiyono. (2014). Educational Research Methods Quantitative, Qualitative Approach and R \& D, Alfabeta, Bandung.

Wibowo. (2012). Work management. PT Raja Grafindo Persada, Jakarta.

Veithzal Rivai. (2014). Human Resource Management for Companies, 6th Edition, PT. Raja Grafindo Persada, Depok, Jakarta. 